\title{
Opposing effects on the cell cycle of T lymphocytes by Fbxo7 via Cdk6 and p27
}

\author{
Shachi P. Patel ${ }^{1} \cdot$ Suzanne J. Randle $^{1} \cdot$ Sarah Gibbs $^{1} \cdot$ Anne Cooke $^{1} \cdot$ Heike Laman $^{1}$
}

Received: 5 August 2016/Revised: 28 October 2016/Accepted: 21 November 2016/Published online: 3 December 2016

(C) The Author(s) 2016. This article is published with open access at Springerlink.com

\begin{abstract}
G_{1}$ phase cell cycle proteins, such as cyclin-dependent kinase 6 (Cdk6) and its activating partners, the D-type cyclins, are important regulators of T-cell development and function. An F-box protein, called F-box only protein 7 (Fbxo7), acts as a cell cycle regulator by enhancing cyclin D-Cdk6 complex formation and stabilising levels of p27, a cyclin-dependent kinase inhibitor. We generated a murine model of reduced Fbxo7 expression to test its physiological role in multiple tissues and found that these mice displayed a pronounced thymic hypoplasia. Further analysis revealed that Fbxo7 differentially affected proliferation and apoptosis of thymocytes at various stages of differentiation in the thymus and also mature T-cell function and proliferation in the periphery. Paradoxically, Fbxo7-deficient immature thymocytes failed to undergo expansion in the thymus due to a lack of Cdk6 activity, while mature $\mathrm{T}$ cells showed enhanced proliferative capacity upon $\mathrm{T}$-cell receptor engagement due to reduced p27 levels. Our studies reveal differential cell cycle regulation by $\mathrm{Fbxo} 7$ at different stages in T-cell development.
\end{abstract}

Keywords Fbxo7 - T-cell development · Cell cycle · Cdk6 - p27

Electronic supplementary material The online version of this article (doi:10.1007/s00018-016-2427-3) contains supplementary material, which is available to authorized users.

Heike Laman

hl316@cam.ac.uk

1 Department of Pathology, University of Cambridge, Cambridge, UK

\section{Introduction}

Fbxo7 (F-box only protein 7) is a multi-functional protein with remarkable tissue-specific effects and is of clinical relevance in a variety of human pathologies, ranging from Parkinson's disease and blood disorders to cancer [1-3]. Fbxo7 is a member of the 69 F-box domain-containing protein family, which function as substrate-docking subunits of SCF (Skp1-Cullin1-F-box)-type E3 ubiquitin ligases [4-8]. These ligases act at the last transference step in the modification of protein substrates by ubiquitin. Substrates of $\mathrm{SCF}^{\mathrm{Fbxo7}}$ ligase include the kinetochore protein HURP, NF- $\mathrm{KB}$ signalling regulators c-IAP and TRAF2, and NRAGE, a protein involved in apoptosis arising from nerve growth factor signalling [9-12]. In addition to this canonical function, Fbxo7 has other welldocumented SCF-independent roles, including acting as a cell cycle regulator in two ways: first, by interacting directly with the G1 phase kinase Cdk6, promoting its binding activation by D-type cyclins, and second, by binding and stabilising the levels of cyclin-dependent kinase inhibitor (CDKI), p27 [1, 13, 14]. This cell cycle regulatory role of $\mathrm{Fbxo7}$ is important in erythropoiesis, and we have reported that the reduction of $\mathrm{Fbxo} 7$ in a mouse causes anaemia, caused by a failure of differentiating erythroblasts to withdraw from the cell cycle due to insufficient levels of p27 [15, 16]. Multiple GWAS studies reinforce the importance of Fbxo7 in red blood cell (RBC) biology as SNPs in FBXO7 are associated with clinically relevant RBC parameters [17-20]. In addition to GWAS studies of the blood, similar studies on families with pedigrees showing cases of the early onset Parkinson's disease revealed the homozygous inheritance of point mutations in FBXO7 to be causative [21-23]. Subsequently, also named PARK15, Fbxo7 was found to interact 
directly with two other genes mutated in Parkinson's disease, PINK1/PARK6, and Parkin/PARK2, to promote mitophagy [24]. Pathogenic point mutations map to functional domains in Fbxo7 including T22M within its $\mathrm{N}$-terminal ubiquitin-like (Ubl) domain that interacts directly with Parkin; R378G adjacent to the F-box domain, which reduces its ability to form an E3 ligase complex; and R498X within one of its substrate-recruiting domains near the end of the protein [3]. Collectively, these mutations point to multiple defects in Fbxo7's many functions as contributing to neurodegeneration. However, as neurons are post-mitotic, this is unlikely to involve its cell cycle regulatory activity.

In addition to its cell cycle regulatory function in erythropoiesis, we reported that Fbxo7 has an anti-proliferative function and a role in promoting the maturation of precursor B lymphocytes, caused by stabilising p27 levels and inhibiting $S$ phase kinase activity [16]. G1 phase cell cycle proteins are known to play key roles in regulating proliferation and maturation of $\mathrm{T}$ lymphocytes in the thymus. Two of the three D-type cyclins are strongly expressed, cyclin D2 before the rearrangement of T-cell receptor (TCR) $\beta$, and cyclin D3 afterwards. These cyclins appear to act primarily through activation of Cdk6, rather than Cdk4. In support of its non-redundant role, Cdk6 knock-out mice have a striking reduction in thymus size and show a block in differentiation at the DN3 stage along with impaired proliferation at the DN2 and DN3 stages [25, 26]. Cyclin D3 null mice also have a small thymus, due to deficient expansion of immature thymocytes at the DN4 stage [27]. Despite cyclin D2 being highly expressed at DN1 to DN3 stages, it is dispensable for T-cell differentiation as cyclin D2 knock-out mice do not show thymic defects, which the authors of that study attributed to compensation by cyclin D3 [28]. Cyclin D3 and Cdk6 are both proto-oncogenes in $\mathrm{T}$ cells, and are overexpressed in T-cell malignancies, like T-ALL and T-cell lymphoma [27]. Moreover, they are thought to function as critical downstream transducers of other oncogenic signalling pathways, like Notch and $\mathrm{p} 65^{\mathrm{Lck}}$. We previously reported that the over-expression of Fbxo7 causes a late-onset T-cell lymphoma after the adoptive transfer of p53 null haematopoietic stem cells (HSCs) transduced to overexpress it. This indicated the potential for increased $\mathrm{Fbxo} 7$ to be oncogenic in $\mathrm{T}$ cells [29]. Given these data, and its capacity to directly bind to Cdk6 and promote cyclin D3/Cdk6 complex formation [13], we reasoned that it would be an important factor in T-cell biology. We report here that loss of Fbxo7 expression in a mouse impairs both thymocyte development and T-cell function. We demonstrate that Fbxo7 expression has opposing roles in cell proliferation within the T-cell lineage at different stages, promoting proliferation of thymocytes within the thymus, but restraining proliferation of activated $\mathrm{T}$ cells in the periphery. This paradoxical activity of Fbxo7 indicates that the G1 phase circuitry during T-cell development is differentially regulated from that of mature $\mathrm{T}$ cells.

\section{Materials and methods}

\section{Mice}

All experimental animals were maintained in accordance with animal licences approved by the Home Office and the University of Cambridge's Animal Welfare and Ethical Review Body Standing Committee, and the ARRIVE guidelines. All work described here was performed under the Home Office licences PPL 80/2474 (expired 2016) and PPL70/9001 (valid until 2021). Fbxo7 ${ }^{\text {LacZ }}$ mice (Fbxo $7^{\text {tm1a(EUCOMM)Hmgu }}$ C57BL/6J background) were maintained in individually ventilated cages with unrestricted access to food and water, and heterozygous animals were bred. WT and homozygous littermates were harvested between 6-8 weeks, unless stated otherwise. Male and female mice were both used for experiments.

For genotyping, crude genomic DNA extraction was performed on ear punch biopsies. Tissue was digested using a solution of $10 \%$ Chelex (BioRad), $100 \mu \mathrm{g} / \mathrm{mL}$ proteinase $\mathrm{K}$, and $0.1 \%$ Tween-20. One microliter of supernatant was used in multiplex genotyping, with a common $5^{\prime}$ forward primer (CAGGATCAGGGAACGCCTGT) and different $3^{\prime}$ reverse primers to amplify the WT (TGCAGGGTGAATAGCACTTCC) or the transgenic (CACAACGGGTTCTTCTGTTAGTCC) allele. The reaction amplifying the WT allele produces a $197 \mathrm{bp}$ product, whereas the reaction amplifying the transgene produces a $362 \mathrm{bp}$ product. The PCR consisted of 35 cycles of 92,62 , and $72{ }^{\circ} \mathrm{C}$ for $30 \mathrm{~s}$ each. Primers pairs spanning an exon-exon boundary were used for qRTPCR of murine Fbxo7 using SYBR Green JumpStart Taq Ready Mix (Sigma) on an iCycler thermocycler (BioRad). Primers used were $5^{\prime}$ (CGCAGCCAAAGTGTACAAAG) and $3^{\prime}$ (AGGTTCAGTACTTGCCGTGTG).

\section{Tissue preparation}

Spleens and thymuses were harvested and disaggregated by passage through a $40 \mu \mathrm{m}$ cell strainer, and splenocytes subjected to RBC ammonium chloride lysis buffer to remove excess RBCs. Cell density was determined by trypan blue (Invitrogen) exclusion using a haemocytometer. 


\section{Flow cytometry and fluorescence activated cell sorting (FACS)}

Single cell suspensions of splenocytes and thymocytes were stained with fluorescently labelled CD4-PE or CD4PECy7 (clone GK1.5) and CD8-APC (clone H35-17.2) antibodies, for $30 \mathrm{~min}$ at $4{ }^{\circ} \mathrm{C}$ in the dark, washed twice with FACS buffer (PBS with $1 \% \mathrm{FBS}$ ), and $\mathrm{CD} 4^{+}$or $\mathrm{CD}^{+}$positive cells analysed using Summit 4.3 software (Beckman Coulter) on a Cyan ADP Analyser (Dako), or sorted in PBS using a MoFlo FACS sorter (Dako). Sorted cells were resuspended in the required media for culturing, or lysed for immunoblotting. Cells were analysed using the following gating strategy for thymocytes and splenocytes (Supplementary Figs. 1A and B, respectively). Thymocytes were also stained with antibodies to CD4-biotin and CD8biotin followed by Streptavidin-FITC, as well as antibodies to CD44-PE (clone IM7), CD25-PECy7 (clone PC61.5), and analysed or sorted using the following gating strategy (Supplementary Fig. 1C). Collected cells were used for cell cycle analysis or immunoblotting. All flow cytometry antibodies were from eBiosciences. For $\mathrm{T}_{\text {Reg }}$ cells, splenocytes were stained for $\mathrm{CD} 3$ and $\mathrm{CD} 4$, before being fixed, permeabilised, and subjected to intracellular Foxp3 staining following the manufacturer's recommendations (eBioscience). Apoptosis was assayed by first staining cells with antibodies to detect specific populations, washed once in Annexin V binding buffer (10 mM HEPES, $140 \mathrm{mM}$ $\mathrm{NaCl}, 2.5 \mathrm{mM} \mathrm{CaCl}_{2}, \mathrm{pH} 7.4$ ), and then stained for Annexin $\mathrm{V}^{+}$cells with Annexin V-Alexa Fluor 647, as per the manufacturer's recommendations (Catalogue no. A23204, Invitrogen). Propidium iodide (PI) was also used at $2.5 \mu \mathrm{g} /$ $\mathrm{mL}$ to discriminate live cells from dead cells.

\section{T-cell activation and cytokine analysis}

For T-cell activation assays, lymphocytes in mixed splenocyte suspensions were counted using a haemocytometer and $2 \times 10^{5}$ cells plated per 96 well, in complete RPMI media (RPMI with $10 \%$ heat inactivated (HI) foetal bovine serum (FBS), $100 \mathrm{U} / \mathrm{mL}$ penicillin and streptomycin, and $5 \mu \mathrm{M}$ 2-mercaptoethanol (all Invitrogen)) supplemented with or without soluble $2 \mu \mathrm{g} / \mathrm{mL}$ anti-CD3e (clone 145-2C11) and $2 \mu \mathrm{g} / \mathrm{mL}$ anti-CD28 (clone 37.51), to activate T cells. Cells were incubated for 24,48 , and $72 \mathrm{~h}$ in a humidified $37{ }^{\circ} \mathrm{C}, 5 \% \mathrm{CO}_{2}$ incubator. To assay for activation markers, cells were analysed by flow cytometry with antibodies to CD4-PE, CD8-APC, CD25-PECy7, and CD69-FITC (clone H1.2F3, eBiosciences). See Supplementary Fig. 1d and e for representative FACS plots. For cytokine analysis, $\mathrm{CD} 4^{+} \mathrm{T}$ cell from spleen were FACS sorted and plated as above. Cells were incubated for 24 and $48 \mathrm{~h}$, and then supernatants collected for cytokine analysis using ELISA assays for IL-2, IFN- $\gamma$, as per the manufacturer's instructions (eBioscience).

\section{Cell cycle analysis}

For carboxy fluorescein succinimidyl ester (CFSE) staining, splenocytes $\left(3 \times 10^{6}\right.$ cells $\left./ \mathrm{mL}\right)$ were incubated with $1 \mu \mathrm{M}$ CFSE (Invitrogen) in PBS for $15 \mathrm{~min}$ in a humidified $37^{\circ} \mathrm{C}, 5 \% \mathrm{CO}_{2}$ incubator. Cells were washed twice with PBS supplemented with 10\% FBS and resuspended in complete RPMI media. CFSE labelled cells $\left(2 \times 10^{5} /\right.$ well in 96-well plates) were seeded in a final volume of $200 \mu \mathrm{L}$ complete RPMI media with soluble anti-CD3 and antiCD28 as described above, and cultured for 48 and $72 \mathrm{~h}$. Cells were analysed for CFSE dilution using flow cytometry. For cell cycle analysis using PI, thymocytes were FACS sorted, and stained as described in [15], and analysed by flow cytometry.

\section{Statistical analyses}

Statistical differences between mutant and WT were calculated using Student's two-tailed $t$ tests with a significant cutoff of $p<0.05$. Data are presented as mean \pm standard deviation. On graphs, ${ }^{*} p<0.05,{ }^{* *} p<0.01,{ }^{* * *} p<0.001$.

\section{Cell lysis}

Sorted cells or whole thymuses were lysed in RIPA buffer (50 mM Tris- $\mathrm{HCl}$ pH 7.6, $150 \mathrm{mM} \mathrm{NaCl}, 1 \% \mathrm{NP}-40,0.1 \%$ SDS, $0.1 \% \mathrm{Na}$ deoxycholate, $1 \times$ protease inhibitors, $1 \mathrm{mM}$ PMSF, $10 \mathrm{mM}$ sodium fluoride, $1 \mathrm{mM}$ sodium orthovanadate) (all from Sigma), and incubated on ice for 30 min with occasional vortexing. Cell debris was pelleted by centrifugation at $16,000 \mathrm{~g}$ for $10 \mathrm{~min}$ at $4{ }^{\circ} \mathrm{C}$. Cell lysates were collected and protein concentration determined using the BCA method in a 96-well plate (Pierce). Protein samples were diluted in lysis buffer to the desired concentration, ensuring equal protein concentrations across all samples.

\section{Immunoblotting}

Protein samples were mixed with equal volumes of $2 \times$ Laemmli buffer and denatured by incubating at $95{ }^{\circ} \mathrm{C}$ for $5 \mathrm{~min}$. Proteins were then separated using Tris-Glycine SDS polyacrylamide gel electrophoresis (SDS-PAGE), and transferred onto polyvinylidene fluoride (PVDF) membrane (Millipore) using a semi-dry transfer system (Biorad). Membranes were blocked for $1 \mathrm{~h}$ with 5\% nonfat, milk powder/PBS-Tween $20(0.05 \%)$ (PBS-T), and then probed with primary antibody overnight at $4{ }^{\circ} \mathrm{C}$ in $5 \%$ non-fat, milk powder/PBS-T. Membranes were washed in 
PBS-T and incubated in the appropriate HRP-conjugated secondary antibody in 5\% non-fat, milk powder/PBS-T followed by further washes, and detection of HRP bound protein using enhanced chemiluminescence (ECL, GE Healthcare) and exposure onto X-ray film (Konica Minolta). Signal was quantified and normalised using the ImageJ software (NIH, Maryland).

\section{Antibodies}

Antibodies for western blotting were used as described in [16], as well as anti-cleaved caspase 3 (9664S), antiphospho pRb Ser780 (8180S), and anti-phospho pRb Ser807/811 (9308S), all from Cell Signalling Technologies, and anti-GAPDH (G9545) and anti- $\gamma$-tubulin (T6557) both from Sigma-Aldrich.

\section{Results}

\section{Defective thymocyte development in $\mathrm{Fbxo}^{\mathrm{LacZ} / \mathrm{LacZ}}$ mutant mice}

The generation of Fbxo $7^{\mathrm{LacZ}}$ mice has been described previously [16], and a schematic of the transgene is shown in Fig. 1a. Expression of Fbxo7 is disrupted by the presence of the $L a c Z$ gene, with a preceding splice acceptor site, between exons 3 and 4 of Fbxo7. The identification of mice with the LacZ insertion was confirmed by multiplex PCR (Fig. 1b) where a common forward primer (half arrows, Fig. 1a) amplifies a 197 base pair product with a reverse primer to WT genomic sequences, or a 362 base pair product with a reverse primer to sequences in the transgene. Mice with homozygous inheritance of an Fbx$\mathrm{o} 7^{\text {LacZ }}$ (mutant) allele consistently had visibly smaller thymuses $(n=45)$ compared to WT mice (Fig. 1c), which were on average $25 \%$ of the mass of WT (Fig. 1d). This phenotype was fully penetrant, and this was quantified as an $80 \%$ reduction in cell number (Fig. 1e). Homozygous Fbxo $7^{\text {LacZ }}$ mice have approximately $80-90 \%$ reduction in Fbxo7 mRNA expression in many tissues, such as liver, spleen, and cerebellum, as shown by qRT-PCR analysis [15]. In the thymus, no Fbxo7 message is detected by qRTPCR analysis [15], and we could not detect any protein expression by immunoblotting of Fbxo $7^{\text {LacZ/LacZ }}$ lysates from whole thymuses (Fig. 1f). Haematoxylin and eosin staining of thymuses harvested from littermate-matched WT and Fbxo $7^{\text {LacZ/LacZ }}$ mice showed intact medulla and cortical thymic compartments with no gross changes in their anatomical structure (Fig. $1 \mathrm{~g}$ ), arguing against premature involution as a cause of hypoplasia.

To investigate the cellular deficiencies in the thymus, the total cell numbers at all T-cell developmental stages were quantified. Single cell suspensions from thymuses from WT and Fbxo $7^{\text {LacZ/LacZ }}$ littermates were stained for CD4 and CD8 (double negative (DN), double positive (DP), and single positive either for $\mathrm{CD}^{+}$or $\mathrm{CD}^{+}$) (Fig. 1h), or for CD25 and CD44 to identify developmental stages within the CD4 and CD8 DN population [CD25 $\mathrm{CD}_{4}{ }^{+}$(DN1), CD25 ${ }^{+} \mathrm{CD}_{4}{ }^{+}$(DN2), CD25 ${ }^{+} \mathrm{CD} 44^{-}$ (DN3), and CD25 ${ }^{-} \mathrm{CD}_{4}^{-}$(DN4)] (Fig. 1i). The absolute cell numbers were significantly reduced at all developmental stages (Fig. 1h, i). The relative proportions at each stage of T-cell differentiation were also determined, and we observed a statistically significant 0.73 -fold increase in the total DN fraction (Fig. 1j), such that this fraction accounted for $9.5 \%$ of total thymocytes in mutant mice compared to $5.5 \%$ in WT mice. No significant differences were seen in the proportions of the DP or SP populations (Fig. 1j). To investigate whether a particular DN stage was affected, the proportion of cells at each DN stage in thymuses from mutant and WT mice were analysed. The percentage of DN1 cells was significantly increased in mutants compared to WT (0.41-fold increase), whereas the percentage of DN4 cells was reduced significantly (0.22fold decrease) in mutants compared to WT (Fig. 1k). This proportional increase in DN1 cells in the mutant mouse must contribute to the statistically significant increase in the DN populations compared to DP and SP populations (Fig. 1j), since the DN2/DN3 proportions are similar and DN4 is reduced in the mutant thymuses (Fig. 1k). Thus,

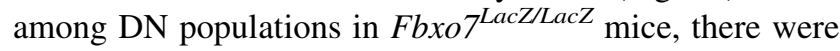
increased DN1 cells and fewer DN4, which may stem from changes in proliferation and/or apoptosis. We noted that when thymuses from mice older than 10 weeks were analysed, the proportions at individual DN stages were unchanged (Supplementary Fig. 2a), indicating that these defects can be compensated for over time.

\section{Reduced numbers of the early thymic progenitors (ETPs) in mutant mice}

A possible cause for thymic hypoplasia might be insufficient seeding of the thymus or defects in the survival or development of ETPs after seeding. To address this, we quantified, by flow cytometry, the number and proportion of bone marrow (BM)-derived ETPs, identified as c-Kit ${ }^{+}$ within the DN1 population $\left(\mathrm{CD} 44^{+} \mathrm{CD} 25^{-} \mathrm{CD} 4^{-}\right.$and $\mathrm{CD}^{-}$) cells. A significant reduction in the percentage (0.45-fold) and absolute number (0.76-fold) of ETPs was observed in Fbxo $7^{\mathrm{LacZ} / \mathrm{LaCZ}}$ mice compared to WT (Fig. 2a, b). Although these data might suggest a BM insufficiency, a previous analysis of haematopoietic progenitor popula-

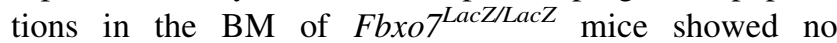
significant changes in the percentages of LMPPs $\left(\mathrm{Lin}^{-}\right.$ Sca- ${ }^{+}{ }^{-}-\mathrm{Kit}^{+} \mathrm{CD}^{+} 4^{+}$and Flt3 ${ }^{+}$) or CLPs (Lin ${ }^{-} \mathrm{IL}-7 \mathrm{R} \alpha^{+}$ 
Fig. 1 Fbxo $7^{\text {LacZ/LacZ }}$ mice have thymic hypoplasia. a Schematic of murine $\mathrm{Fbxo} 7$ locus with WT and targeted allele, Fbxo $7^{\text {tm1a(EUCOMM)Hmgu }}$, showing LacZ/neo insertion with splice acceptor (SA) site and poly-A tails (pA). Primers used for multiplex genotyping are shown (half arrows). b Multiplex PCR reaction showing amplification of WT (197 bp) and mutant (362 bp) alleles in WT, heterozygous (het), and homozygous LacZ (mutant) mice. The same forward primer is used in both reactions. c Photograph of thymuses from 2- to 4-monthold littermate WT and Fbxo $7^{\text {LacZ/LacZ }}$ mutant mice, from 3 L. d Quantification of thymus weight from 2- to 4-month-old mice $(n=4$ WT and $n=8$ mutant mice from 4 L). e Total thymic cellularity of WT $(n=6)$ and $\mathrm{Fbxo}^{\mathrm{LacZ}}$ ${ }_{\text {LacZ }}(n=5)$. f Lysates made from thymuses from WT, heterozygous, and homozygous Fbxo $7^{\text {LacZ }}$ mice were analysed by immunoblotting for $\mathrm{Fbxo} 7$ and $\operatorname{actin}(n=1)$. g H\&Estained sections of WT and Fbxo $7^{\text {LacZ/LacZ }}$ thymus showing medullary (pink) and cortical (blue) compartments. Scale bars $200 \mu \mathrm{m}(n=3$ from $2 \mathrm{~L})$.

h Total cell number of indicated populations in WT $(n=6)$ and Fbxo $7^{\text {LacZ/LacZ }}(n=5)$

thymuses. i Total cell number at each DN stage in WT $(n=7)$ and $\mathrm{Fbxo}^{\text {LacZ/LacZ }}(n=6)$ thymuses. j, k Graphs showing percentages of cells in each thymocyte subpopulation from WT $(n=21)$ and $\mathrm{Fbxo}^{\mathrm{LacZ}}$ LacZ $(n=18)$ thymuses. Data are represented as mean $\pm \mathrm{SD}$, $* p<0.05, * * p<0.01$, $* * * p<0.001$ a

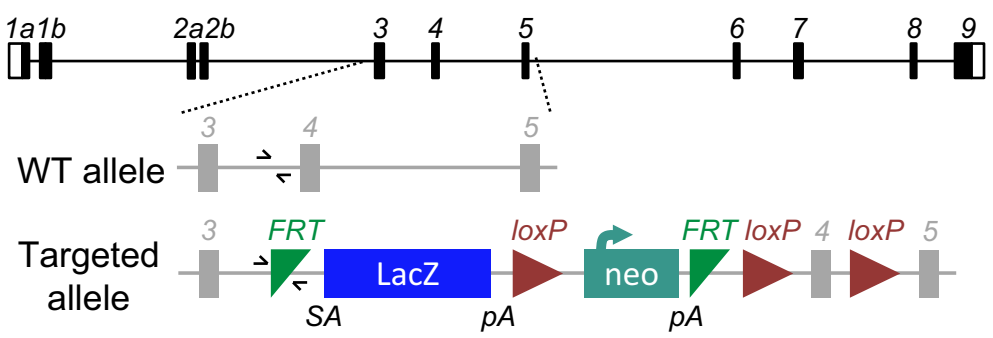

b

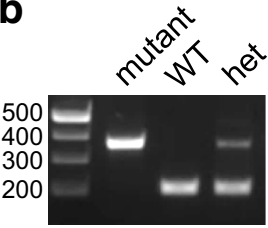

C

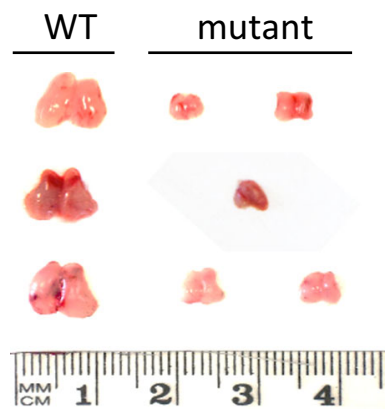

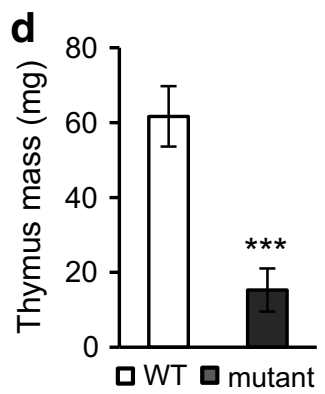

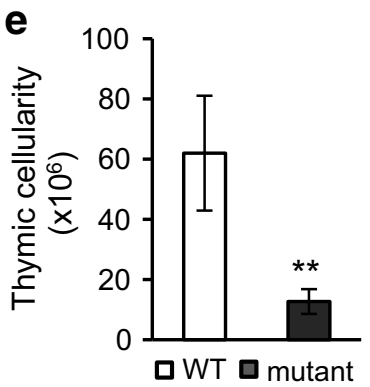

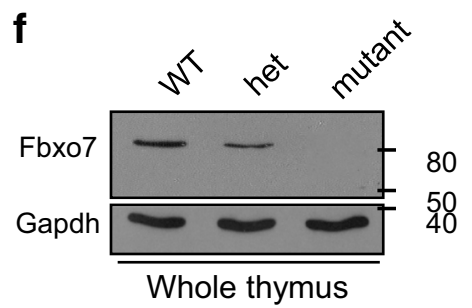

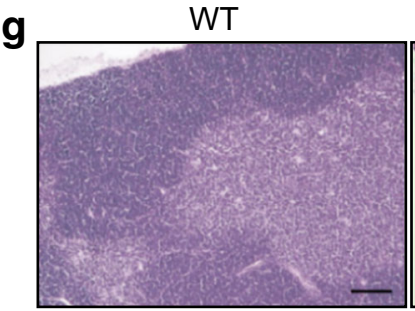

mutant

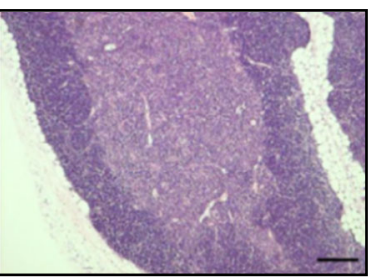

h
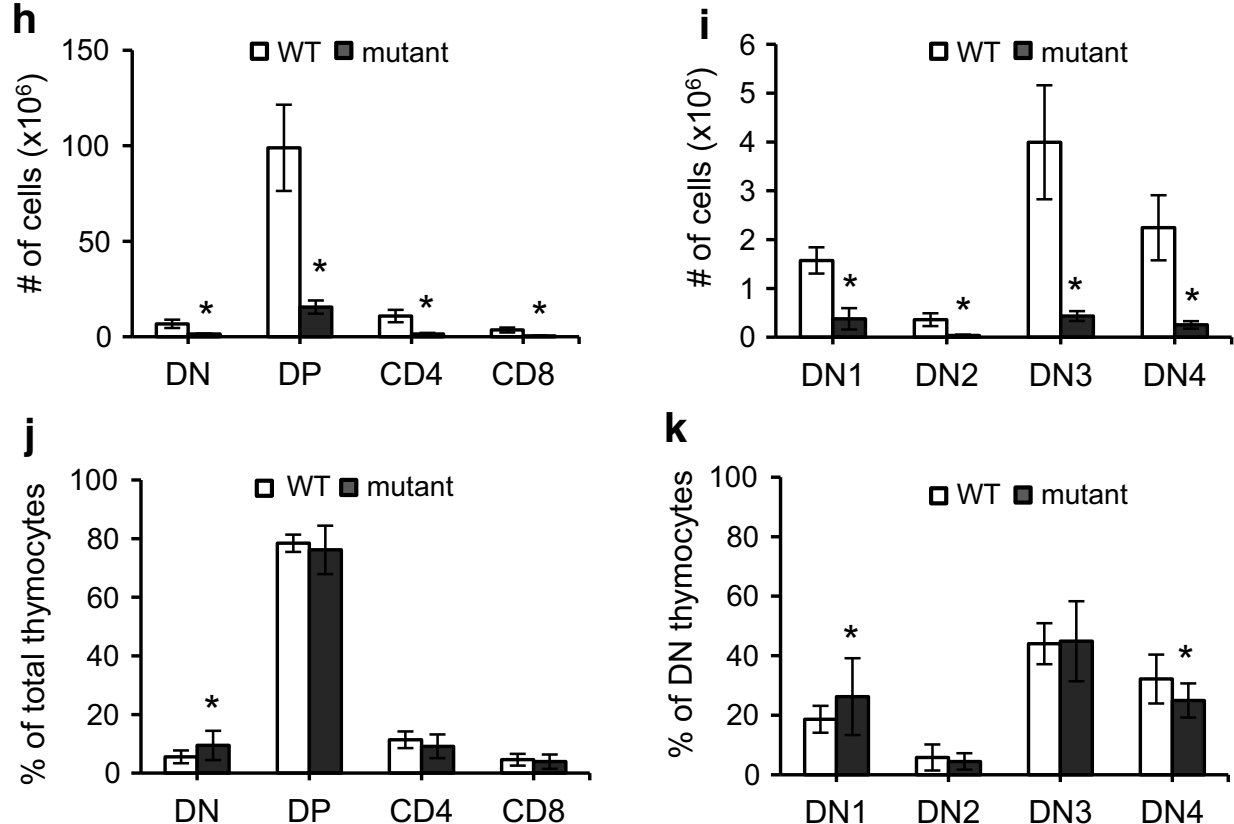

k

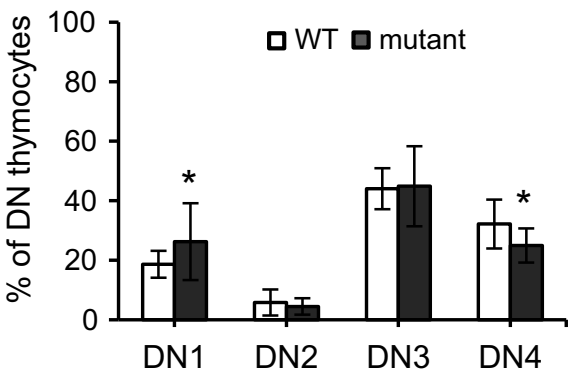

and $\mathrm{Flt}^{+}$) compared to WT [15]. These data argue against a depleted progenitor pool in the BM as a cause of hypoplasia, but demonstrate the presence of fewer ETP cells in the thymus of mutant mice. This might occur due to reduced seeding of the thymus or decreased viability of ETPs within the thymus. 
Fig. 2 Decreased proliferation and increased apoptosis in the thymuses of $\mathrm{Fbxo}^{\text {LacZ/LacZ }}$ mice. a, b Graphs showing ETPs as a percentage of DN1 population (a) and as total number in thymuses (b) in WT $(n=4)$ and Fbxo $7^{\text {LacZ/LacZ }}$

$(n=4)$ thymuses. c Annexin V staining of DN1-4 populations from WT $(n=13)$ and Fbxo $7^{\text {LacZ/LacZ }}(n=12)$ thymuses. Data represented as mean $\pm \mathrm{SD}, * p<0.05$. d Immunoblotting for cleaved caspase 3 of lysates made from whole thymuses from animals of the indicated genotypes $(n=1)$. e Graph showing percentage of cells in $S / G_{2} / M$ phases of the cell cycle in each FACS sorted population from WT and Fbxo $7^{\text {LacZ/LacZ }}$ thymuses pooled from 15 mice. Data show mean of four independent experiments. $* p<0.05, * * p<0.01$. f, g Representative western blot of lysates from FACS sorted DN1, $\mathrm{DN} 3$, and DN4 thymocytes, from four pooled WT and Fbxo $^{\text {LacZLLacZ }}$ thymuses, showing cell cycle regulatory proteins (f), or phosphorylated $\mathrm{pRb}$ (g). GAPDH and Ponceau $\mathrm{S}$ staining were used as a protein loading control as indicated. These experiments were repeated twice

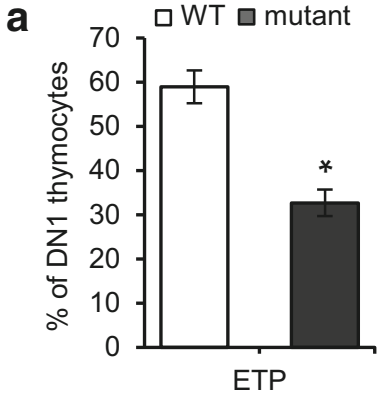

C

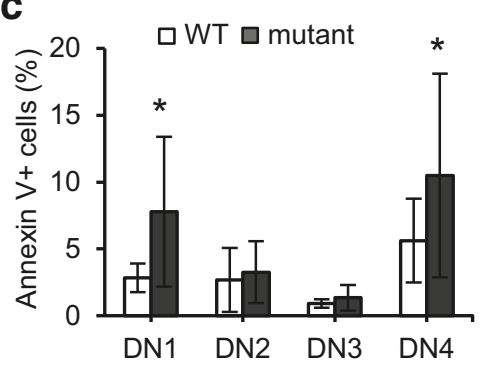

e

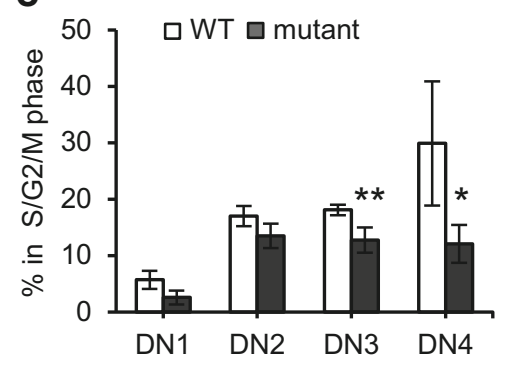

g

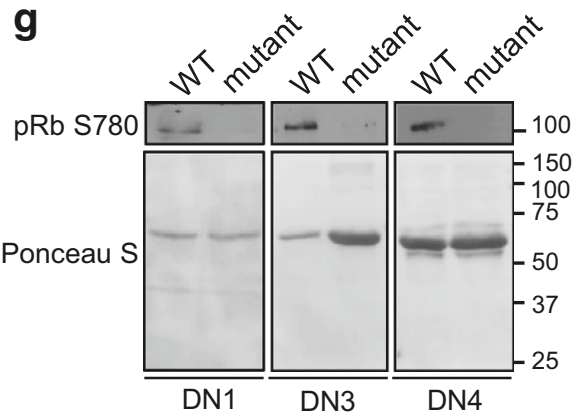

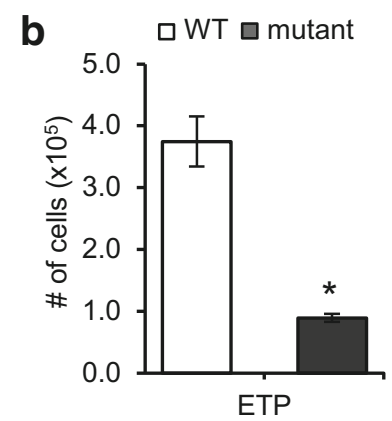

d
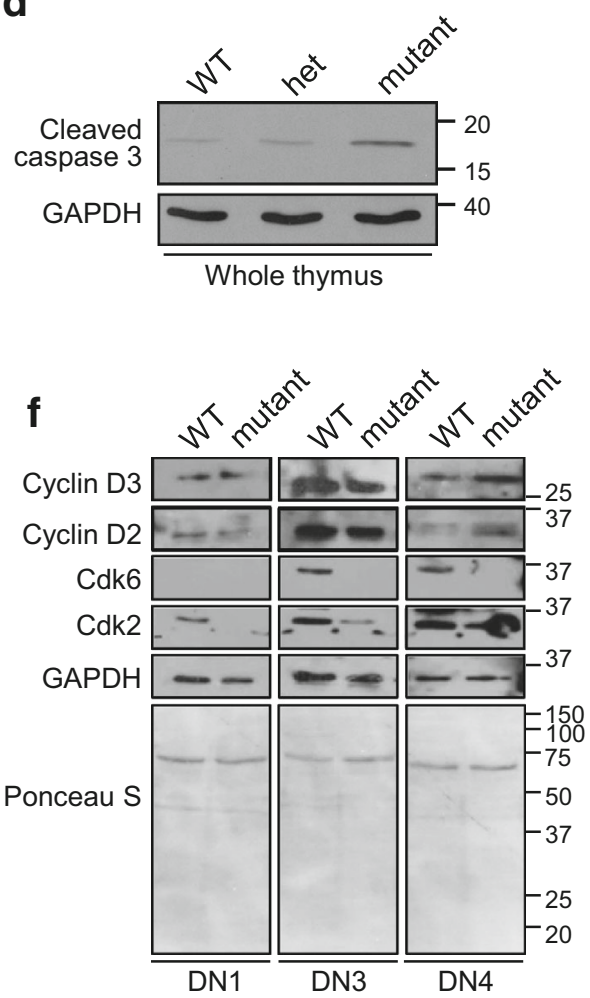

\section{Increased apoptosis and reduced proliferation of mutant DN thymocytes}

We next investigated whether changes in the rates of apoptosis and/or proliferation within thymic subsets might account for the observed differences in mutant mice. To test this, thymocytes at all developmental stages were stained for Annexin V (Fig. 2c). Flow cytometry analysis showed a 1.74- and 0.87-fold increase in Annexin V staining at the DN1 and DN4 stages, respectively, in mutant cells compared to WT. There were no significant differences in Annexin $\mathrm{V}^{+}$cells at the other DP, CD4 SP, and CD8 SP stages (Supplementary Fig. 2b). To further test this finding, immunoblotting of whole cell extracts of thymuses for cleaved caspase 3 showed that mice homozygous for the $\mathrm{Fbxo} 7^{\mathrm{LacZ}}$ allele had the highest levels (Fig. 2d), supporting the idea that apoptosis levels increased when Fbxo7 expression was reduced.

We also tested whether the proliferation of thymocytes was altered. As an indicator of cell cycle phase, the DNA content was analysed by staining sorted DN populations with PI. Cells in $G_{0} / G_{1}$ phase ( $2 \mathrm{~N}$ DNA) and $S / G_{2} / M$ phases ( $>2 \mathrm{~N}$ DNA) were quantified and expressed as a percentage for each DN population. There was no 
statistically significant change in the percentage of cycling cells at the DN1 and DN2 stages. However, cycling cells (with $>2 \mathrm{~N}$ DNA content) were significantly reduced by $29.5 \%$ in the DN3 population and by $59.5 \%$ in the DN4 population in mutant mice compared to WT (Fig. 2e). These data indicated that $\mathrm{Fbxo} 7$ is important for the proliferative burst that occurs at the DN3 and DN4 stages. Taken together, these data indicate that Fbxo7 loss causes deficiencies at multiple stages, including at the earliest DN1 stage, where we observed reduced ETP numbers and increased apoptosis, reduced proliferation at the DN3 stage, and both increased apoptosis and reduced proliferation at the DN4 stage in mutant mice.

\section{Lack of Cdk6 expression in Fbxo $7^{\text {LacZ/LacZ }}$ thymocytes}

Fbxo7 promotes the assembly of D-type cyclins with Cdk6 $[13,14]$, and thymocyte proliferation has been shown to be crucially dependent on Cdk6 [25, 26, 30]. To determine whether the absence of Fbxo7 affected the expression of these G1 cell cycle regulators, DN1/3/4 thymocytes from WT and Fbxo $7^{\text {LacZ/LacZ }}$ mutant mice were harvested, and cell lysates analysed by immunoblotting (Fig. 2f). The numbers of DN2 cells recovered were insufficient for analysis, due to the reduced cellularity of mutant thymuses and small percentage of DN2 cells. The most obvious difference seen was that Cdk6 was undetectable in samples from mutant mice, and there was also a reduction in Cdk2 levels compared to WT samples. In addition, in mutant DN4 thymocytes, there were increased levels of cyclins D2 and D3 compared to WT, but in DN1 and DN3 cells, D-type cyclin levels were similar (Fig. 2f).

To further investigate the molecular effect of the loss of Cdk6, we tested for its activity in DN populations by immunoblotting using phospho-specific antibodies for $\mathrm{pRb}$ phosphorylation at Ser780, as modification at this residue is used as a marker of cyclin D/Cdk6 activity. Equal numbers of DN1/3/4 cells from WT and mutant mice were harvested, and cell lysates were immunoblotted. All DN thymocytes from WT mice had readily detectable phosphoSer780 $\mathrm{pRb}$ in contrast to DN thymocytes from mutant mice where none was detected (Fig. $2 \mathrm{~g}$ ). These data indicate that Cdk6 activity was absent in the tested DN populations of $\mathrm{Fbxo} 7^{\mathrm{LacZ} / \mathrm{LaCZ}}$ mutant mice, and support the idea that Fbxo7 promotes cyclin D-Cdk6 activity, which promotes the proliferation of immature thymocytes.

\section{Fbxo ${ }^{\text {LacZ/LacZ }}$ mice have fewer $\mathrm{CD4}^{+}$and $\mathrm{CD8}^{+} \mathrm{T}$ cells in the periphery}

A lack of Fbxo7 expression resulted in significantly fewer cells differentiating to the SP stages within the thymus
(Fig. 1h). To assess the effect on mature $\mathrm{T}$ cells in the periphery, the percentage and absolute numbers of peripheral $\mathrm{CD}^{+}{ }^{+}$and $\mathrm{CD}^{+} \mathrm{T}$ cells were determined by counting $\mathrm{T}$ cells in the spleen. Fbxo $7^{\text {LacZ/LacZ }}$ mice have significantly enlarged spleens due to extramedullary haematopoiesis; however, splenic cellularity of mutant mice was comparable to WT littermates after the lysis of RBCs, indicating that the increase is due mostly to erythroid lineage cells [15]. Mature $\mathrm{T}$ cells were stained using antibodies to CD4 and CD8 surface markers and analysed by flow cytometry. There were 0.74 - and 0.77 -fold reductions in the proportions of $\mathrm{CD}^{+}$and $\mathrm{CD}^{+} \mathrm{T}$ cells in spleens from mutant mice compared to WT (Fig. 3a). The absolute number of $\mathrm{CD}^{+}$and $\mathrm{CD}^{+} \mathrm{T}$ cells was also significantly reduced, in mutant mice (Fig. 3b). These data showed a significant reduction in peripheral $\mathrm{CD}^{+}$and $\mathrm{CD}^{+}$effector $\mathrm{T}$ cells of $\mathrm{Fbxo} 7^{\text {LacZ/LacZ }}$ mice, consistent with the reduced cellularity observed in the thymus.

Within the CD4 population, we also tested whether mutant mice had altered numbers of Foxp ${ }^{+}$regulatory $\mathrm{T}$ cells $\left(\mathrm{T}_{\mathrm{Reg}}\right)$ which suppress the immune response. Splenocytes were harvested and stained for CD4, CD25, and Foxp3. Although the number of $\mathrm{CD}^{+}{ }^{+}$Foxp $^{+}$cells was the not significantly different between WT and mutant mice, proportionally, there was a statistically significant 0.75 -fold increase in $\mathrm{CD}^{+}{ }^{+}$Foxp $^{+} \mathrm{T}_{\text {Reg }}$ cells, due to the overall decrease in effector $\mathrm{T}$ cells in mutant mice (Fig. 3c, d).

\section{$\mathrm{CD4}^{+}$and $\mathrm{CD8}^{+} \mathrm{T}$ cells lacking $\mathrm{Fbxo7}$ showed delayed activation}

To assess the role of Fbxo7 in T-cell activation in the mature $\mathrm{CD}^{+}{ }^{+}$and $\mathrm{CD}^{+}{ }^{+} \mathrm{T}$-cell populations, we assayed for the expression of surface markers CD69 and CD25 after TCR stimulation with soluble antibodies to CD3 and CD28. Equal numbers of $\mathrm{T}$ cells were analysed, and both $\mathrm{CD}^{+}$and $\mathrm{CD}^{+}{ }^{+}$T-cell populations from mutant mice showed significantly fewer double positive cells $(16 \%$ fewer for $\mathrm{CD}^{+}$and $6 \%$ for $\mathrm{CD}^{+} \mathrm{T}$ cells) compared to WT at $24 \mathrm{~h}$ after TCR stimulation, (Fig. 4a, Supplementary Fig. 1d, e). At $48 \mathrm{~h}$ post-stimulation, the percentages of WT and mutant $\mathrm{CD}^{+}$and $\mathrm{CD}^{+} \mathrm{T}$ cells expressing both activation markers were comparable. In the absence of stimulation by $\mathrm{CD} 3 / \mathrm{CD} 28$, no $\mathrm{CD} 25^{+} \mathrm{CD} 69^{+}$cells were detected. Thus, both $\mathrm{CD}^{+}{ }^{+}$and $\mathrm{CD}^{+}{ }^{+} \mathrm{T}$ cells show delayed activation in the absence of $\mathrm{Fbxo7}$, indicating a requirement for Fbxo7 function in the timely activation of $\mathrm{T}$ cells.

\section{Fbxo7-deficient $T$ cells expand more rapidly after TCR engagement}

T-cell activation is followed by rapid increases in cell number, with cell doubling times reported to be as little as 
Fig. 3 Decreased numbers of CD4 and CD8 T cells in the spleen of $\mathrm{Fbxo} 7^{\text {LacZ/LacZ }}$ mice. a, b Graphs showing the percentage (a) and absolute cell number (b) of $\mathrm{CD}^{+}$and $\mathrm{CD}^{+} \mathrm{T}$ cells in WT and Fbxo $7^{\text {LacZ/LacZ }}$ spleens $(n=10)$. c Graph showing percentage of Foxp $3^{+} \mathrm{T}_{\text {Reg }}$ cells in $\mathrm{CD}^{+}$population in spleen $(n=5)$. d Total number of $\mathrm{CD}^{+}{ }^{+} \mathrm{Foxp}^{+} \mathrm{T}_{\mathrm{Reg}}$ in WT and Fbxo $7^{\text {LacZLLacZ }}$ mutant spleens $(n=5)$. All data are represented as mean $\pm \mathrm{SD}$, $* p<0.05$
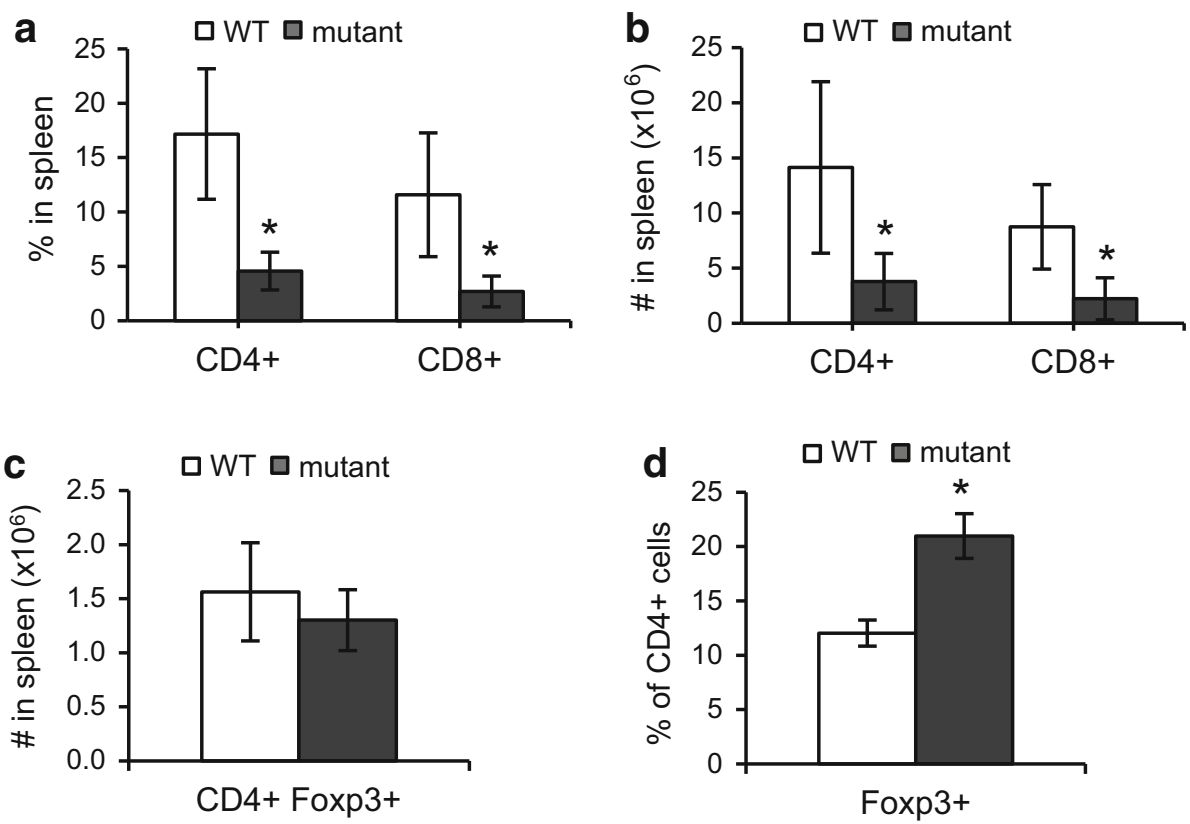

$4.5 \mathrm{~h}$ [31], and differentiation into effector T cells. We next tested whether proliferation was altered in mutant cells. Splenocytes were stimulated with soluble antibodies to $\mathrm{CD} 3$ and $\mathrm{CD} 28$, and the percentages of $\mathrm{CD}^{+}$and $\mathrm{CD} 8^{+} \mathrm{T}$ cells were monitored over 3 days. At the outset, $\mathrm{CD} 4^{+} \mathrm{T}$ cells comprised $16.4 \%$ of WT and $5.9 \%$ of mutant splenocyte cultures (Supplementary Fig. 2c). After 24 h, this number was largely unchanged in both cultures. However, by $72 \mathrm{~h}$, the percentage of $\mathrm{CD}^{+}{ }^{+} \mathrm{T}$ cells in WT cultures was $13.1 \%$ and comparable to the percentage of CD4 cells in mutant cultures of $11.4 \%$. When the fold change in absolute cell number was calculated, mutant $\mathrm{CD}^{+} \mathrm{T}$ cells had expanded by 1.27 - and 2.06 -fold at 48 and $72 \mathrm{~h}$ compared to the starting number, whereas WT $\mathrm{CD}^{+} \mathrm{T}$ cells expanded 1.27 fold by $48 \mathrm{~h}$ but was back to day 0 numbers by $72 \mathrm{~h}$ (Fig. 4b, left). Thus, the significant difference between the numbers of WT and mutant CD4 cells observed at the start of the assay was lost by $72 \mathrm{~h}$ due to the more rapid expansion of mutant $\mathrm{CD}^{+}{ }^{+}$cells (Supplementary Fig. 2c).

A similar analysis was performed for $\mathrm{CD} 8^{+} \mathrm{T}$ cells. At day 0 , there were significantly fewer $\mathrm{CD}^{+} \mathrm{T}$ cells in mutant cultures: $2.6 \%$ compared to $9.2 \%$ in WT samples (Supplementary Fig. 2d). By 72 h, Fbxo $7^{\text {LacZ/LacZ }}$ and WT cultures contained 25.9 and $34.7 \% \mathrm{CD}^{+} \mathrm{T}$ cells, respectively, showing that both WT and $\mathrm{Fbxo} 7^{\text {LacZ/LacZ }} \mathrm{CD} 8$ cells expanded robustly. However, when the fold change in absolute cell number was calculated, $\mathrm{Fbxo} 7^{\mathrm{LacZ} / \mathrm{LacZ}}$ cultures had expanded to a much greater extent over $72 \mathrm{~h}$ (Fig. 4b, right). At 48 and $72 \mathrm{~h}$, WT cells expanded 2.3- and 4.7-fold compared to 2.9and 10.6-fold expansion of mutant cells at the same time points. Notably, despite their greater expansion, quantification of the absolute CD4 and CD8 cell number in activated cultures over the course of the experiment showed that the number of mutant $\mathrm{T}$ cells did not exceed that of WT T cells (Supplementary Fig. 2e, f), These data demonstrated that activated $\mathrm{CD}^{+}{ }^{+}$and $\mathrm{CD} 8^{+} \mathrm{T}$ cells lacking Fbxo7 increased in numbers significantly more than WT cells.

\section{Fbxo $7^{\text {LacZ/LacZ }} \mathrm{T}$ cells cycle more rapidly after activation}

To investigate the observed greater increase in the numbers of mutant $\mathrm{T}$ cells following activation, we tested whether activated $\mathrm{T}$ cells showed changes in their rates of proliferation. After treatment with RBC lysis buffer, equal numbers of WT and mutant splenocytes were first labelled with a fluorescent dye CFSE and then incubated with CD3 and CD28 antibodies. Flow cytometry was used to monitor CFSE dilution as an indicator of cell divisions at 48 and $72 \mathrm{~h}$ post-activation in both $\mathrm{CD}^{+}$and $\mathrm{CD} 8^{+}$cells (Fig. 4 c). At 48 h, $74.6 \%$ of mutant $\mathrm{CD}^{+}{ }^{+} \mathrm{T}$ cells had undergone 3 or more cell divisions compared to $36.9 \%$ in WT samples (Fig. 4c, top row), and by $72 \mathrm{~h}, 77.7 \%$ of $\mathrm{CD}^{+}{ }^{+}$mutant $\mathrm{T}$ cells had divided 5 or more times compared to $35.3 \%$ in WT cultures (Fig. 4c, bottom row). Similarly, at $48 \mathrm{~h}, 94.2 \%$ of $\mathrm{CD}^{+}$mutant $\mathrm{T}$ had divided 3 or more times compared to $57.8 \%$ in WT samples (Fig. 4c, top row), and by $72 \mathrm{~h}, 99.7 \% \mathrm{CD}^{+}$mutant $\mathrm{T}$ cells had undergone 5 or more cell divisions compared to $83.1 \%$ in WT cultures (Fig. 4c, bottom row). These data show that after activation, Fbxo7 mutant $\mathrm{T}$ cells cycle significantly 
Fig. 4 Delayed activation and more rapid expansion of mutant splenic $\mathrm{CD} 4^{+}$and $\mathrm{CD} 8^{+} \mathrm{T}$ cells. a Graph showing the percentage of CD69 and CD25 double positive $\mathrm{CD}^{+}($left $)$and $\mathrm{CD} 8^{+}$(right) $\mathrm{T}$ cells in stimulated WT and Fbxo $7^{\text {LacZ/ }}$ ${ }_{\text {LacZ }}$ spleen cultures at 24 and 48 h post-stimulation $(n=10)$. b Graphs showing fold expansion in WT and Fbxo $7^{\text {LacZ/LacZ }} \mathrm{CD}^{+}$(left) and $\mathrm{CD}^{+}$(right) T-cell numbers, normalised to day 0 , at indicated time points in spleen cultures after CD3 and CD28 stimulation $(n=5)$. c Representative histograms displaying CFSE dilution of WT and $\mathrm{Fbxo}^{\mathrm{LacZ}}$ ${ }_{\text {LacZ }} \mathrm{CD}^{+} \mathrm{T}$ (left) and

$\mathrm{CD}^{+}$(right) $\mathrm{T}$ cells at 48 (top two histograms) and 72 (bottom two histograms) $\mathrm{h}$ after TCR engagement $(n=7)$. d, e Graphs showing the levels of IL-2 (d) and IFN- $\gamma$ (e) from FACS sorted WT and Fbxo $7^{\text {LacZ/LacZ }} \mathrm{CD} 4^{+} \mathrm{T}$ cells cultures after 24 and $48 \mathrm{~h}$ of TCR stimulation with CD3 and CD28 $(n=5)$. For all experiments, data represented as mean \pm SD. $* p<0.05$,

$* * * p<0.001$
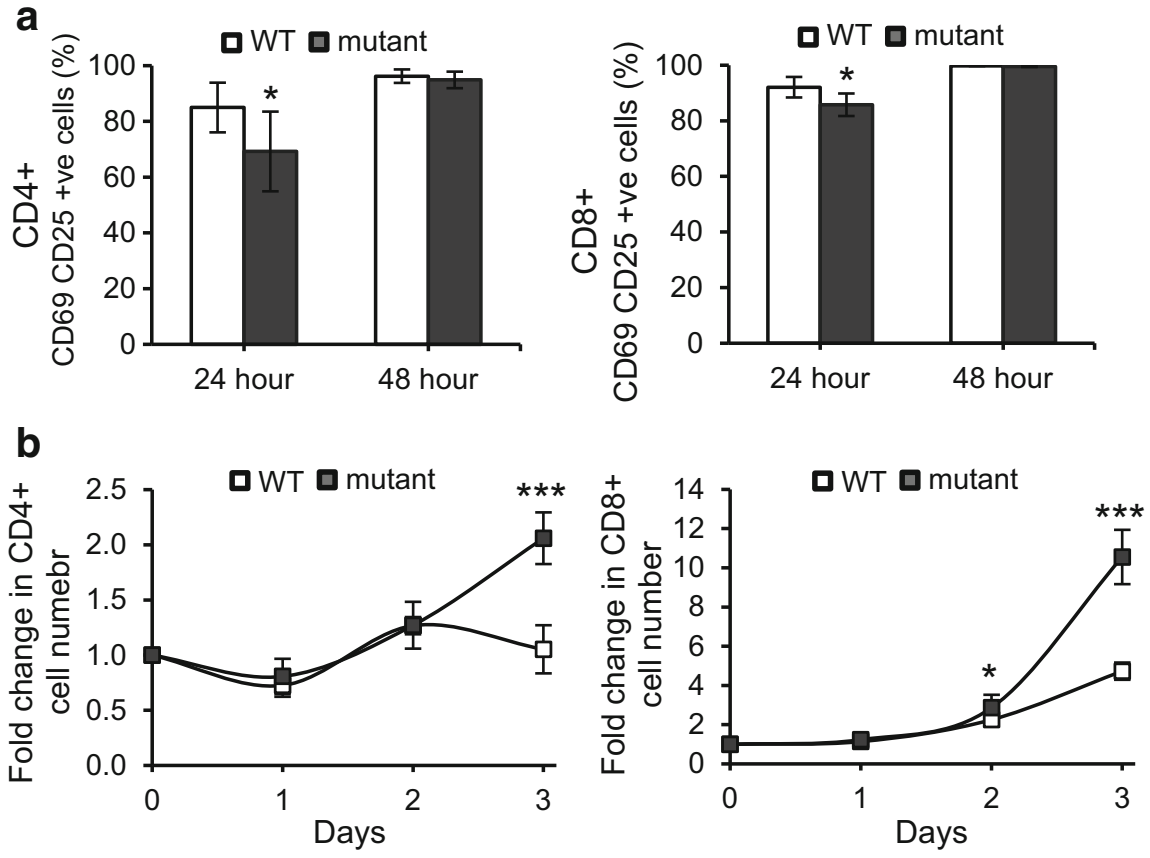

C
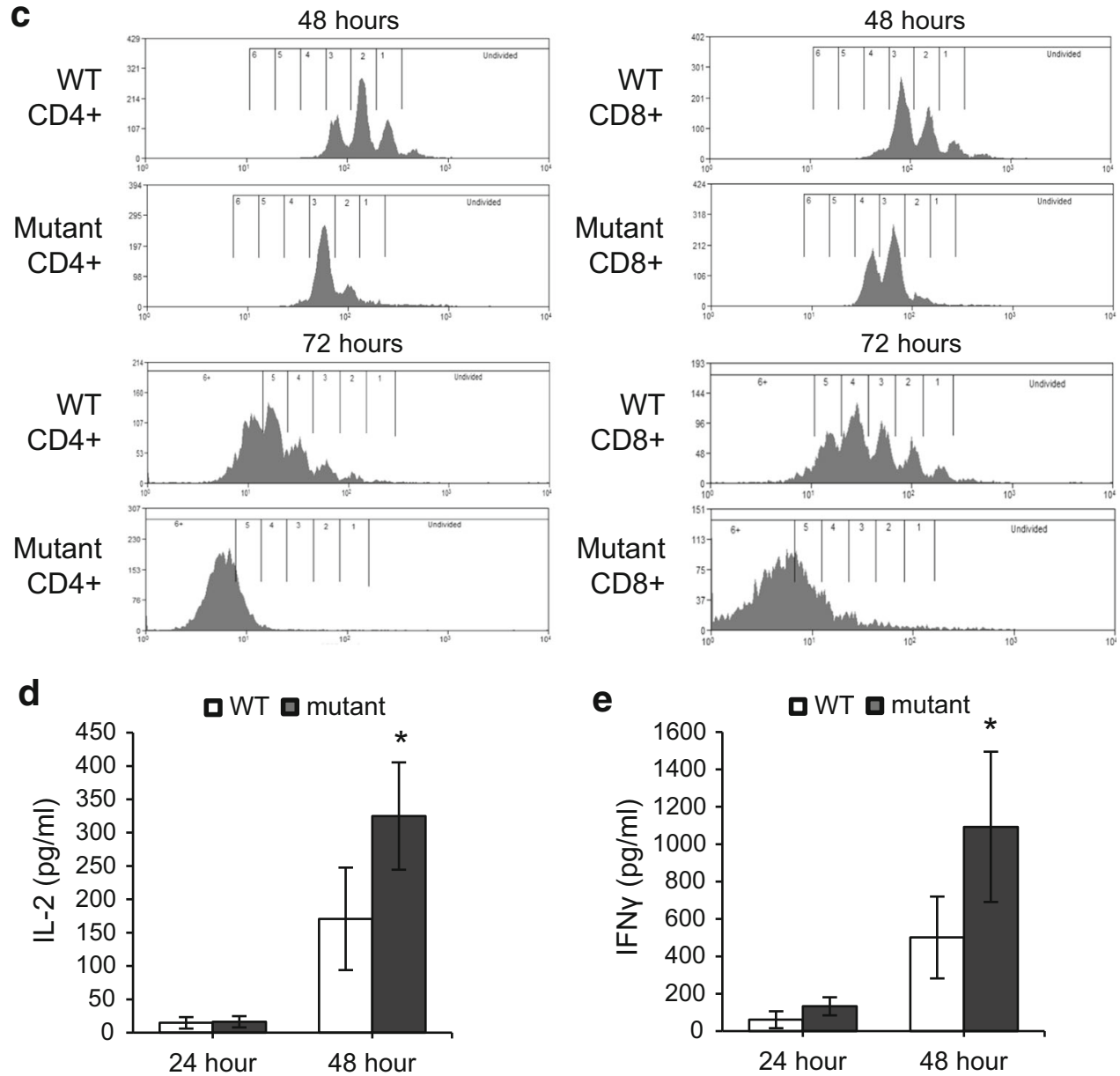
faster than WT cells, and indicate an anti-proliferative role for Fbxo7 in the proliferation of activated $\mathrm{T}$ cells.

\section{Increased IL-2 and IFN- $\gamma$ production by $\mathrm{Fbxo}^{\mathrm{LacZ} /}$ ${ }^{\text {LacZ }} \mathrm{CD4}^{+} \mathrm{T}$ cells}

Upon TCR activation, naive $\mathrm{CD} 4^{+} \mathrm{T}$ cells may differentiate into one of several Th lineages, each defined by their pattern of cytokine production and function. We tested for Th1 and Th2 cytokines secreted by isolated WT and mutant $\mathrm{CD} 4^{+} \mathrm{T}$ cells after TCR activation with soluble antibodies to CD3 and CD28 molecules. At 24 and $48 \mathrm{~h}$, after TCR activation, supernatants from $\mathrm{T}$ cells cultures were collected and cytokines concentrations were measured using ELISAs. Levels of Th1 and Th2 cytokines were assayed to give an overview of effector functions of $\mathrm{CD} 4^{+} \mathrm{T}$ cells. At $24 \mathrm{~h}$, the IL-2 concentration in mutant $\mathrm{CD}^{+} \mathrm{T}$ samples was comparable to WT samples, and at $48 \mathrm{~h}$, the IL-2 concentration was on average $325 \mathrm{pg} / \mathrm{mL}$ in mutant CD4 ${ }^{+}$ T-cell samples compared to $171 \mathrm{pg} / \mathrm{mL}$ in WT samples, a 1.9-fold increase (Fig. 4d). Similarly, at 48 h post-stimulation, mutant CD4 cells produced $1093 \mathrm{pg} / \mathrm{mL}$ of IFN- $\gamma$ compared to $501 \mathrm{pg} / \mathrm{mL}$ in WT cultures, representing a 2.2-fold increase, which was statistically significant (Fig. 4e). These results indicated that mutant $\mathrm{CD} 4^{+} \mathrm{T}$ cells produced a Th1 cytokine response similar to WT, suggesting that subsequent activation of other immune cells, such as macrophages, and $\mathrm{CD} 8^{+} \mathrm{T}$ cells would be possible in Fbxo $7^{\text {LacZ/LacZ }}$ mice. The levels of IL-4 and IL-10, indicative of a Th2 response, were also determined, and both were similar in WT and mutant samples (data not shown). These results showed that activated mutant $\mathrm{CD} 4^{+}$ $\mathrm{T}$ cells were capable of producing both Th1 and Th2 cytokines. The approximate twofold increase in the production of IL-2 and IFN- $\gamma$ despite overall fewer cell numbers may be a due to the more rapid proliferation of mutant CD4 cells upon activation.

\section{Increased apoptosis in resting and activated mutant $\mathrm{CD4}^{+}$and $\mathrm{CD8}^{+} \mathrm{T}$ cells}

Since mutant $\mathrm{T}$ cells expanded more rapidly than WT cells after activation, we tested whether the capacity to undergo apoptosis was inhibited which might also contribute to the observed increased expansion upon activation. To determine the percentage of $\mathrm{T}$ cells undergoing apoptosis, WT and mutant splenocytes were stimulated as above. At 48 and $72 \mathrm{~h}$ of TCR stimulation, cells were removed and costained with antibodies to CD4 and CD8 along with Annexin V (Fig. 5a, b). Interestingly, there were significantly more apoptotic mutant $\mathrm{CD}^{+} \mathrm{T}$ cells: $43.3 \%$ compared to $12.8 \%$ for WT cultures at $48 \mathrm{~h}$, and $30.6 \%$ compared to $9.9 \%$ at $72 \mathrm{~h}$, reflecting a 2.4 and 2.1 fold increase, respectively, in stimulated mutant $\mathrm{CD}^{+}$cells (Fig. 5a). In contrast, $48 \mathrm{~h}$ post-stimulation, $9.5 \%$ of mutant $\mathrm{CD}^{+} \mathrm{T}$ cells were Annexin $\mathrm{V}^{+}$compared to $5.3 \%$ cells in WT samples, a difference which was not statistically significant $(P=0.051)$. At $72 \mathrm{~h}$, both cultures had approximately 5\% Annexin $\mathrm{V}^{+}$cells (Fig. 5b). Thus, mutant $\mathrm{CD}^{+}{ }^{+} \mathrm{T}$ cells, but not $\mathrm{CD} 8^{+} \mathrm{T}$ cells, showed significantly increased levels of apoptosis after activation, and demonstrate that apoptosis induction was not suppressed in mutant $\mathrm{T}$ cells. The higher rates of apoptosis in $\mathrm{CD} 4^{+}$ compared to $\mathrm{CD} 8^{+}$cells ( $\sim 13$ vs. $5 \%$ for WT cultures) may contribute to the more limited expansion of CD4 cells relative to $\mathrm{CD} 8$ cells observed in culture (Supplementary Fig. 2e, f).

Resting $\mathrm{T}$ cells are thought to be more resistant to apoptosis than activated $\mathrm{T}$ cells. To investigate if increased apoptosis was also observed in resting $\mathrm{T}$ cells, unstimulated splenocytes from mutant and WT mice were also tested for staining with Annexin V (Fig. 5c). Flow cytometry analysis showed significantly greater numbers of Annexin $\mathrm{V}^{+}$mutant $\mathrm{CD}^{+}{ }^{-}$and $\mathrm{CD}^{+}{ }^{+} \mathrm{T}$ cells. There was a 0.93 -fold increase in the number of Annexin $\mathrm{V}^{+}$cells: $27.2 \%$ mutant $\mathrm{CD}^{+}$ cells compared to $14.1 \%$ in WT mice, and about a 0.4 -fold increase in Annexin $\mathrm{V}^{+}$mutant $\mathrm{CD} 8^{+}$cells: $54.9 \%$ compared to $39.4 \%$ in WT mice (Fig. 5c). These results indicated that resting $\mathrm{T}$ cells in the periphery of mutant mice undergo higher levels of apoptosis, which suggests that they may a have shorter lifespan. This may contribute to the decreased number of mature $\mathrm{T}$ cells present in the periphery, and suggests that $\mathrm{Fbxo7}$ may regulate molecular pathways governing the survival of resting $\mathrm{T}$ cells.

\section{Fbxo $7^{\text {LacZ/LacZ }} \mathrm{T}$ cells have less p27}

p27 is a critical mediator of T-cell quiescence, and TCR crosslinking causes both transcriptional and translational down-regulation of $\mathrm{p} 27$, leading to increased cyclin $\mathrm{E} / \mathrm{Cdk} 2$ and $\mathrm{A} / \mathrm{Cdk} 2$ activity, which promotes $\mathrm{S}$ phase entry [32]. We hypothesized that one mechanism to account for the more rapid cycling and increased apoptosis seen in mutant $\mathrm{T}$ cells might be reduced $\mathrm{p} 27$ levels. $\mathrm{CD} 4^{+}$ and $\mathrm{CD} 8^{+} \mathrm{T}$ cells were isolated from spleens, and equal numbers of cells from each population were lysed. Protein lysates were immunoblotted, and both $\mathrm{CD}^{+}$and $\mathrm{CD} 8^{+}$ mutant $\mathrm{T}$ cells showed reduced p27 levels (Fig. 5d). One consequence of reduced p27 expression would be a reduced inhibitory threshold for the activation of late $G_{1}$ and $S$ phase cyclin $\mathrm{E} / \mathrm{Cdk} 2$ and $\mathrm{A} / \mathrm{Cdk} 2$ activities. This would facilitate cell proliferation in activated $\mathrm{T}$ cells or directly induce apoptosis in quiescent cells, if appropriate secondary stimuli were not present. To test whether $\mathrm{Cdk}$ activity was increased in quiescent cells, phospho-specific antibodies to detect $\mathrm{pRb}$ modification were used to probe 
Fig. 5 Decreased levels of p27 in mutant $\mathrm{T}$ cells. a, b Graphs showing the percentage of Annexin $\mathrm{V}$ positive cells in activated WT and mutant $\mathrm{CD}^{+}$(a) and $\mathrm{CD}^{+}(\mathbf{b}) \mathrm{T}$ cells at 48 and $72 \mathrm{~h}$ after TCR stimulation of splenocyte cell cultures $(n=10)$. c Graph showing the percentage of Annexin $\mathrm{V}$ positive cells in naïve $\mathrm{CD}^{+}{ }^{+}$and $\mathrm{CD} 8^{+} \mathrm{T}$ cells in WT and $\mathrm{Fbxo}^{\text {LacZ/LacZ }}$ spleens $(n=4)$. For all experiments, data represented as mean \pm SD. $* p<0.05$. d, e Representative images of western blot of lysates made from equal numbers of FACS sorted $\mathrm{CD}^{+}{ }^{+}$and $\mathrm{CD} 8^{+} \mathrm{T}$ cells from WT and Fbxo $7^{\text {LacZ/LacZ }}$ spleens. Due to low numbers of mature $\mathrm{T}$ cells, mutant cells were pooled from 5 (d) or 4 (e) mutant mice. These experiments were repeated twice
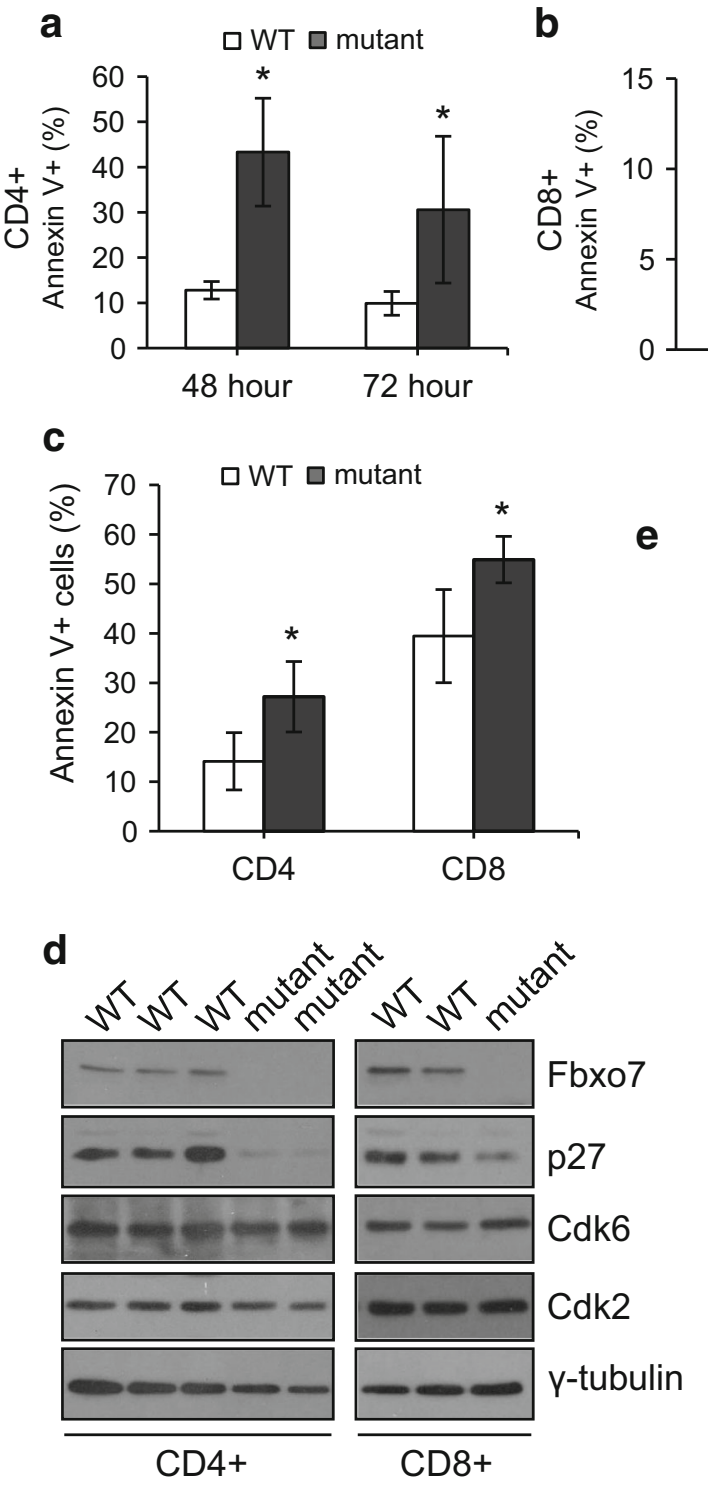

b

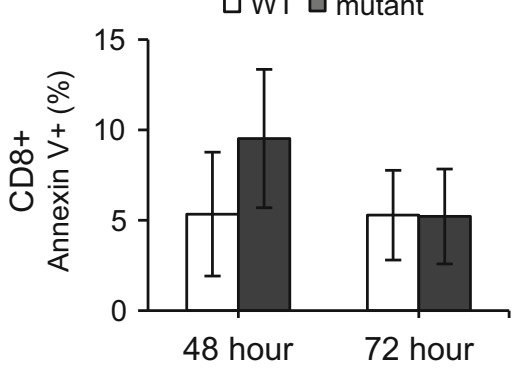

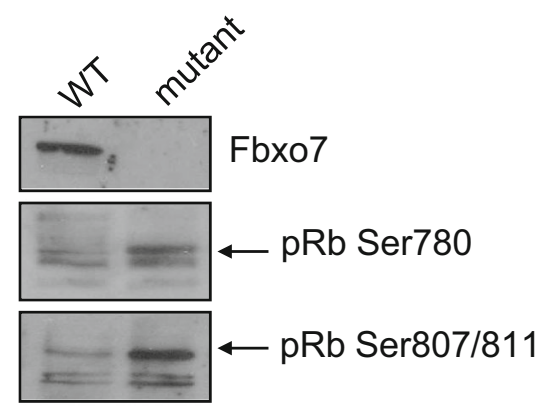

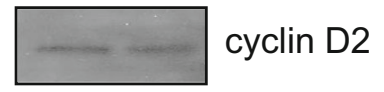
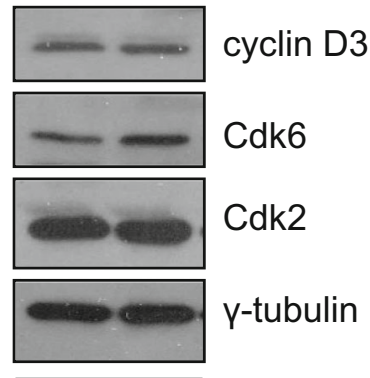

CD4+ cell lysates from resting $\mathrm{CD} 4^{+} \mathrm{T}$ cells purified as in $5 \mathrm{~d}$. We observed increased signals for phosphorylation at Ser780 and at Ser807/811, indicating inactivation of pRb (Fig. 5e). Interestingly, Cdk6 expression was similar in mutant and WT cells, indicating that in peripheral $\mathrm{T}$ cells, Fbxo7 is not required to stabilize its expression or its activation by D-type cyclins. These data indicate that increased proliferation and apoptosis in Fbxo $7^{\text {LacZ/LacZ }} \mathrm{T}$ cells may be explained by reduced $\mathrm{p} 27$ expression and increased overall Cdk activity, but not levels.

\section{Discussion}

Our data on the defects within the T-cell lineage that arise due to the absence of $\mathrm{Fbxo7}$ expression reveal its critical activities at different stages of development and function.
Most striking is the fact that Fbxo7 has opposing roles in regulating cell cycle proliferation in a single cell type, stemming from its ability to act as a scaffold and stabilizer of the levels of Cdk6 and p27, whose functions appear to predominate at different times in T-cell biology [13-16]. During the development of $\mathrm{T}$ cells in the thymus, Fbxo7 appears to be required for proliferation at the DN3/DN4 stages, yet in the periphery, it functions to restrain proliferation after T-cell activation, as evidenced by the very rapid cell division of mature $\mathrm{T}$ cells after they are $\mathrm{CD} 3 /$ CD28 stimulated.

The roles of Cdk6 and p27 within the thymus have been independently tested using knock-out mouse models. The previously reported Cdk6 null mouse models both have reduced cellularity in their thymus $[25,30]$. Deficiencies in cell number disproportionately decreased the immature thymocyte populations; however, small increases in thymic 
$\mathrm{SP} \mathrm{CD} 4{ }^{+}$and $\mathrm{CD}^{+}$cell numbers were observed. DN2 and DN3 cells showed reduced proliferation, and reduced apoptosis was observed at DN3, DN4, and SP cells. In the periphery, mature Cdk6 null $\mathrm{T}$ cells were slower to proliferate after mitogenic stimulation, although overall numbers of peripheral $\mathrm{T}$ lymphocytes were comparable to WT. These studies indicate that Cdk6 regulates the differentiation of thymocytes and the proliferative response of activated $\mathrm{T}$ lymphocytes. Fbxo7-deficient mice mimicked certain phenotypes of the Cdk6 null mouse, most obvious being that mutant DN cells showed no Cdk6 expression or any evidence of Cdk6 activity as shown by the absence of Ser780 pRb, which is the likely defect underlying the failure of DN3/DN4 cells to proliferate in mutant mice. Cyclin D3 KO mice also show proliferative defects at the DN3/DN4 stages [27]. Both cyclin partners D2 and D3 were detected in mutant mice, so the lack of Cdk6 was not due to their absence. Indeed, the inability to detect Cdk6 in mutant cells may be due to its inability to assemble with cyclin D2 and D3 in the absence of Fbxo7, which causes Cdk6 destabilisation. Cyclins D2 and D3 may interact with the other Cdks, 4 or 2, neither of which interact with Fbxo7 [13], but neither of which can substitute for Cdk6 activity at this critical stage in T-cell development [26, 30]. In contrast to the Cdk6 null and Fbxo $7^{\mathrm{LacZ}}$ mouse models, the three p27 KO mouse models demonstrate enlarged thymuses, with no alterations to T-cell development [33-35], suggesting that mis-regulation of p27 plays a minimal role in the thymic phenotype observed in Fbxo $7^{\text {LacZ }}$ mice. An additional, unique defect we uncovered within the Fbxo7deficient thymus was at the ETP/DN1 stage, where we observed decreased numbers of ETPs and also increased apoptosis of DN1 cells. These data indicated multiple defects in T-cell development at the earliest settling of the thymus by precursor cells, and their later proliferative expansion stages at the DN3/DN4 stages, along with increased apoptosis at the DN4 stage. The absence of Cdk6 at the DN3 and DN4 stages is likely to underlie the failure of these cells to expand; however, Cdk6 was not detected at the DN1 stage, and is, therefore, unlikely to account for the defects then.

Within the spleen, Fbxo $7^{\text {LacZ/LacZ }}$ mice had fewer mature $\mathrm{CD}^{+}{ }^{+}$and $\mathrm{CD}^{+} \mathrm{T}$ cells, which displayed delayed activation, similar to Cdk6 null cells [25, 26], yet faster proliferation upon activation, which is likely to be due to decreased levels of p27 and the inactivation of $\mathrm{pRb}$ seen in these cells. Indeed, the latter phenotype is akin to that of p27 KO T cells, which have been shown to have increased numbers of cells in $\mathrm{S}$ phase, higher cyclin $\mathrm{E}$ activated kinase activity, and increased responsiveness to mitogens [33]. However, these cells also showed no changes in their levels of apoptosis, suggesting that their increased Cdk activity leads to increased cell proliferation and hyperplasia rather than cell death [33]. Both naïve $\mathrm{CD}^{+}{ }^{+}$and $\mathrm{CD}^{+}{ }^{+} \mathrm{T}$ cells and activated $\mathrm{CD} 4^{+} \mathrm{T}$ cells from Fbxo7-deficient animals showed increased levels of apoptosis, which suggests that aberrant cell signalling, rather than increased proliferation, is leading to increased cell death. Notably, since $\mathrm{CD}^{+} \mathrm{T}$ cells proliferate faster and more robustly than $\mathrm{CD}^{+}{ }^{+} \mathrm{T}$ cells, yet do not show increased apoptosis levels, this argues against enhanced proliferation as the cause of apoptosis. An alternate possibility is that increased proliferation contributes to increased apoptosis, but mutant $\mathrm{CD}^{+} \mathrm{T}$ cells lacking Fbxo7 expression were protected from death due to the presence of growth factor(s) in the cultures providing survival signals. For instance, IL- 2 secreted by activated $\mathrm{CD}^{+}{ }^{+} \mathrm{T}$ cells and to lesser extent by activated $\mathrm{CD}^{+} \mathrm{T}$ cells is a key regulator of T-cell apoptosis. IL-2 levels together with the intensity of antigenic stimulation influence the viability of activated $\mathrm{T}$ cells [36]. A third possibility is that $\mathrm{Fbxo} 7^{\mathrm{LacZ} / \mathrm{LaCZ}} \mathrm{CD}^{+} \mathrm{T}$ cells may also undergo increased levels of apoptosis, but the effect is offset by their high proliferation rate.

Overall, Fbxo $7^{\text {LacZ/LaCZ }}$ mice show a dramatically reduced number of peripheral $\mathrm{T}$ cells which show delayed activation. Moreover, within their significantly reduced CD4 T-cell population, they show a proportional increase in $\mathrm{T}_{\text {Reg }}$ cells, which may limit their immune responses. However, once activated both CD4 and CD8 cells proliferate robustly, despite the higher levels of apoptosis of CD4 cells. In addition, activated Fbxo7-deficient CD4 ${ }^{+}$ cells were capable of producing both Th1 and Th2 response cytokines and produced $\sim$ twofold more IL- 2 and IFN- $\gamma$. Collectively, these attributes suggest that these mice may be compromised in their immune responses. In support of this idea, we noted the results of a Salmonella typhimurium challenge using 6-week-old C57BL/6-Fbx$\mathrm{o} 7^{\mathrm{tm} 1 \mathrm{a}(\mathrm{EUCOMM}) \mathrm{Wtsi}}$ mice performed by the Mouse Phenotyping Consortium. Their study showed that these mice had a significantly increased susceptibility to Salmonella-induced morbidity, with significantly higher bacterial counts in the spleen, liver, and caecal contents of Fbxo7-deficient mice compared to WT (Wellcome Trust Sanger Institute, Cambridge UK; personal communication) [37].

In addition to the extensive perturbations in the production and function of T cells caused by the loss of Fbxo7, our findings demonstrate the differential regulation of the G1 phase of the cell cycle in this cell lineage. These effects, which differ from the phenotypes of the single Cdk6 or p27 KO mouse models, reflect the capacity of Fbxo7 to act as a cell cycle regulator that directly impacts on both proteins that clearly provide non-redundant and critical functions at different stages in the development and functioning of $\mathrm{T}$ cells. 
Acknowledgements This work was supported by the University of Cambridge, Department of Pathology Nina King studentship and the Biotechnology and Biological Sciences Research Council (BB/ J007846/1), and the Cambridge Fund for the Prevention of Disease. We are grateful to N. Miller for assistance with flow cytometry.

Open Access This article is distributed under the terms of the Creative Commons Attribution 4.0 International License (http:// creativecommons.org/licenses/by/4.0/), which permits unrestricted use, distribution, and reproduction in any medium, provided you give appropriate credit to the original author(s) and the source, provide a link to the Creative Commons license, and indicate if changes were made.

\section{References}

1. Nelson DE, Randle SJ, Laman H (2013) Beyond ubiquitination: the atypical functions of $\mathrm{Fbxo7}$ and other F-box proteins. Open Biol 3:130131

2. Randle SJ, Laman H (2015) F-box protein interactions with the hallmark pathways in cancer. Semin, Cancer Biol

3. Randle SJ, Laman H (2016) Structure and function of Fbxo7/ PARK15 in Parkinson's disease. Curr Protein Pept, Sci

4. Spruck CH, Strohmaier HM (2002) Seek and destroy: SCF ubiquitin ligases in mammalian cell cycle control. Cell Cycle $1: 250-254$

5. Jackson PK, Eldridge AG (2002) The SCF ubiquitin ligase: an extended look. Mol Cell 9:923-925

6. Lee EK, Diehl JA (2014) SCFs in the new millennium. Oncogene 33:2011-2018

7. Willems AR, Schwab M, Tyers M (2004) A hitchhiker's guide to the cullin ubiquitin ligases: SCF and its kin. Biochim Biophys Acta 1695:133-170

8. Hermand D (2006) F-box proteins: more than baits for the SCF? Cell Div 1:30

9. Hsu JM, Lee YC, Yu CT, Huang CY (2004) Fbx7 functions in the SCF complex regulating Cdk1-cyclin B-phosphorylated hepatoma up-regulated protein (HURP) proteolysis by a proline-rich region. J Biol Chem 279:32592-32602

10. Chang YF, Cheng CM, Chang LK, Jong YJ, Yuo CY (2006) The F-box protein $\mathrm{Fbxo} 7$ interacts with human inhibitor of apoptosis protein cIAP1 and promotes cIAP1 ubiquitination. Biochem Biophys Res Commun 342:1022-1026

11. Kang J, Chung KC (2015) The F-box protein FBXO7 positively regulates bone morphogenetic protein-mediated signaling through Lys-63-specific ubiquitination of neurotrophin receptorinteracting MAGE (NRAGE). Cell Mol Life Sci 72:181-195

12. Kuiken HJ, Egan DA, Laman H, Bernards R, Beijersbergen RL, Dirac AM (2012) Identification of F-box only protein 7 as a negative regulator of NF-kappaB signalling. J Cell Mol Med 16:2140-2149

13. Laman H, Funes JM, Ye H, Henderson S, Galinanes-Garcia L, Hara E, Knowles P, McDonald N, Boshoff C (2005) Transforming activity of $\mathrm{Fbxo} 7$ is mediated specifically through regulation of cyclin D/cdk6. EMBO J 24:3104-3116

14. Laman H (2006) Fbxo7 gets proactive with cyclin D/cdk6. Cell Cycle 5(3):279-282

15. Randle SJ, Nelson DE, Patel SP, Laman H (2015) Defective erythropoiesis in a mouse model of reduced $\mathrm{Fbxo} 7$ expression due to decreased p27 expression. J Pathol 237:263-272

16. Meziane EK, Randle SJ, Nelson DE, Lomonosov M, Laman H (2011) Knockdown of Fbxo7 reveals its regulatory role in proliferation and differentiation of haematopoietic precursor cells. J Cell Sci 124:2175-2186

17. Ganesh SK, Zakai NA, van Rooij FJ, Soranzo N, Smith AV, Nalls MA, Chen MH, Kottgen A, Glazer NL, Dehghan A, Kuhnel B, Aspelund T, Yang Q, Tanaka T, Jaffe A, Bis JC, Verwoert GC, Teumer A, Fox CS, Guralnik JM, Ehret GB, Rice K, Felix JF, Rendon A, Eiriksdottir G, Levy D, Patel KV, Boerwinkle E, Rotter JI, Hofman A, Sambrook JG, Hernandez DG, Zheng G, Bandinelli S, Singleton AB, Coresh J, Lumley T, Uitterlinden AG, Vangils JM, Launer LJ, Cupples LA, Oostra BA, Zwaginga JJ, Ouwehand WH, Thein SL, Meisinger C, Deloukas P, Nauck M, Spector TD, Gieger C, Gudnason V, van Duijn CM, Psaty BM, Ferrucci L, Chakravarti A, Greinacher A, O'Donnell CJ, Witteman JC, Furth S, Cushman M, Harris TB, Lin JP (2009) Multiple loci influence erythrocyte phenotypes in the CHARGE Consortium. Nat Genet 41:1191-1198

18. Ding K, Shameer K, Jouni H, Masys DR, Jarvik GP, Kho AN, Ritchie MD, McCarty CA, Chute CG, Manolio TA, Kullo IJ (2012) Genetic Loci implicated in erythroid differentiation and cell cycle regulation are associated with red blood cell traits. Mayo Clin Proc 87:461-474

19. van der Harst P, Zhang W, Mateo Leach I, Rendon A, Verweij N, Sehmi J, Paul DS, Elling U, Allayee H, Li X, Radhakrishnan A, Tan ST, Voss K, Weichenberger CX, Albers CA, Al Hussani A, Asselbergs FW, Ciullo M, Danjou F, Dina C, Esko T, Evans DM, Franke L, Gogele M, Hartiala J, Hersch M, Holm H, Hottenga JJ, Kanoni S, Kleber ME, Lagou V, Langenberg C, Lopez LM, Lyytikainen LP, Melander O, Murgia F, Nolte IM, O'Reilly PF, Padmanabhan S, Parsa A, Pirastu N, Porcu E, Portas L, Prokopenko I, Ried JS, Shin SY, Tang CS, Teumer A, Traglia M, Ulivi S, Westra HJ, Yang J, Zhao JH, Anni F, Abdellaoui A, Attwood A, Balkau B, Bandinelli S, Bastardot F, Benyamin B, Boehm BO, Cookson WO, Das D, de Bakker PI, de Boer RA, de Geus EJ, de Moor MH, Dimitriou M, Domingues FS, Doring A, Engstrom G, Eyjolfsson GI, Ferrucci L, Fischer K, Galanello R, Garner SF, Genser B, Gibson QD, Girotto G, Gudbjartsson DF, Harris SE, Hartikainen AL, Hastie CE, Hedblad B, Illig T, Jolley J, Kahonen M, Kema IP, Kemp JP, Liang L, Lloyd-Jones H, Loos RJ, Meacham S, Medland SE, Meisinger C, Memari Y, Mihailov E, Miller K, Moffatt MF, Nauck M, Novatchkova M, Nutile T, Olafsson I, Onundarson PT, Parracciani D, Penninx BW, Perseu L, Piga A, Pistis G, Pouta A, Puc U, Raitakari O, Ring SM, Robino A, Ruggiero D, Ruokonen A, Saint-Pierre A, Sala C, Salumets A, Sambrook J, Schepers H, Schmidt CO, Sillje HH, Sladek R, Smit JH, Starr JM, Stephens J, Sulem P, Tanaka T, Thorsteinsdottir U, Tragante V, van Gilst WH, van Pelt LJ, van Veldhuisen DJ, Volker U, Whitfield JB, Willemsen G, Winkelmann BR, Wirnsberger G, Algra A, Cucca F, d'Adamo AP, Danesh J, Deary IJ, Dominiczak AF, Elliott P, Fortina P, Froguel P, Gasparini P, Greinacher A, Hazen SL, Jarvelin MR, Khaw KT, Lehtimaki T, Maerz W, Martin NG, Metspalu A, Mitchell BD, Montgomery GW, Moore C, Navis G, Pirastu M, Pramstaller PP, Ramirez-Solis R, Schadt E, Scott J, Shuldiner AR, Smith GD, Smith JG, Snieder H, Sorice R, Spector TD, Stefansson K, Stumvoll M, Tang WH, Toniolo D, Tonjes A, Visscher PM, Vollenweider P, Wareham NJ, Wolffenbuttel BH, Boomsma DI, Beckmann JS, Dedoussis GV, Deloukas P, Ferreira MA, Sanna S, Uda M, Hicks AA, Penninger JM, Gieger C, Kooner JS, Ouwehand WH, Soranzo N, Chambers JC (2012) Seventy-five genetic loci influencing the human red blood cell. Nature 492:369-375

20. Soranzo N, Spector TD, Mangino M, Kuhnel B, Rendon A, Teumer A, Willenborg C, Wright B, Chen L, Li M, Salo P, Voight BF, Burns P, Laskowski RA, Xue Y, Menzel S, Altshuler D, Bradley JR, Bumpstead S, Burnett MS, Devaney J, Doring A, Elosua R, Epstein SE, Erber W, Falchi M, Garner SF, Ghori MJ, Goodall AH, Gwilliam R, Hakonarson HH, Hall AS, Hammond 
N, Hengstenberg C, Illig T, Konig IR, Knouff CW, McPherson R, Melander O, Mooser V, Nauck M, Nieminen MS, O'Donnell CJ, Peltonen L, Potter SC, Prokisch H, Rader DJ, Rice CM, Roberts R, Salomaa V, Sambrook J, Schreiber S, Schunkert H, Schwartz SM, Serbanovic-Canic J, Sinisalo J, Siscovick DS, Stark K, Surakka I, Stephens J, Thompson JR, Volker U, Volzke H, Watkins NA, Wells GA, Wichmann HE, Van Heel DA, TylerSmith C, Thein SL, Kathiresan S, Perola M, Reilly MP, Stewart AF, Erdmann J, Samani NJ, Meisinger C, Greinacher A, Deloukas P, Ouwehand WH, Gieger C (2009) A genome-wide metaanalysis identifies 22 loci associated with eight hematological parameters in the HaemGen consortium. Nat Genet 41:1182-1190

21. Di Fonzo A, Dekker MC, Montagna P, Baruzzi A, Yonova EH, Correia GL, Szczerbinska A, Zhao T, Dubbel-Hulsman LO, Wouters CH, De Graaff E, Oyen WJ, Simons EJ, Breedveld GJ, Oostra BA, Horstink MW, Bonifati V (2009) FBXO7 mutations cause autosomal recessive, early-onset parkinsonian-pyramidal syndrome. Neurology 72:240-245

22. Paisan-Ruiz C, Guevara R, Federoff M, Hanagasi H, Sina F, Elahi E, Schneider SA, Schwingenschuh P, Bajaj N, Emre M, Singleton AB, Hardy J, Bhatia KP, Brandner S, Lees AJ, Houlden H (2010) Early-onset L-dopa-responsive parkinsonism with pyramidal signs due to ATP13A2, PLA2G6, FBXO7 and spatacsin mutations. Mov Disord 25:1791-1800

23. Shojaee S, Sina F, Banihosseini SS, Kazemi MH, Kalhor R, Shahidi GA, Fakhrai-Rad H, Ronaghi M, Elahi E (2008) Genome-wide linkage analysis of a Parkinsonian-pyramidal syndrome pedigree by $500 \mathrm{~K}$ SNP arrays. Am J Hum Genet 82:1375-1384

24. Burchell VS, Nelson DE, Sanchez-Martinez A, Delgado-Camprubi M, Ivatt RM, Pogson JH, Randle SJ, Wray S, Lewis PA, Houlden H, Abramov AY, Hardy J, Wood NW, Whitworth AJ, Laman H, Plun-Favreau H (2013) The Parkinson's disease-linked proteins Fbxo7 and Parkin interact to mediate mitophagy. Nat Neurosci 16:1257-1265

25. Malumbres M, Sotillo R, Santamaria D, Galan J, Cerezo A, Ortega S, Dubus P, Barbacid M (2004) Mammalian cells cycle without the D-type cyclin-dependent kinases Cdk4 and Cdk6. Cell 118:493-504

26. Hu MG, Deshpande A, Schlichting N, Hinds EA, Mao C, Dose M, Hu GF, Van Etten RA, Gounari F, Hinds PW (2011) CDK6 kinase activity is required for thymocyte development. Blood 117:6120-6131
27. Sicinska E, Aifantis I, Le Cam L, Swat W, Borowski C, Yu Q, Ferrando AA, Levin SD, Geng Y, von Boehmer H, Sicinski P (2003) Requirement for cyclin D3 in lymphocyte development and $\mathrm{T}$ cell leukemias. Cancer Cell 4:451-461

28. Lam EW, Glassford J, Banerji L, Thomas NS, Sicinski P, Klaus GG (2000) Cyclin D3 compensates for loss of cyclin D2 in mouse B-lymphocytes activated via the antigen receptor and CD40. J Biol Chem 275:3479-3484

29. Lomonosov M, Meziane K, Ye H, Nelson DE, Randle S, Laman $\mathrm{H}$ (2011) Expression of Fbxo7 in haematopoietic progenitor cells cooperates with p53 loss to promote lymphomagenesis. PLoS One 6:e21165

30. Hu MG, Deshpande A, Enos M, Mao D, Hinds EA, Hu GF, Chang R, Guo Z, Dose M, Mao C, Tsichlis PN, Gounari F, Hinds PW (2009) A requirement for cyclin-dependent kinase 6 in thymocyte development and tumorigenesis. Cancer Res 69:810-818

31. Kurts C, Kosaka H, Carbone FR, Miller JF, Heath WR (1997) Class I-restricted cross-presentation of exogenous self-antigens leads to deletion of autoreactive CD8(+) T cells. J Exp Med 186:239-245

32. Zhang S, Lawless VA, Kaplan MH (2000) Cytokine-stimulated T lymphocyte proliferation is regulated by p27Kip1. J Immunol 165:6270-6277

33. Fero ML, Rivkin M, Tasch M, Porter P, Carow CE, Firpo E, Polyak K, Tsai LH, Broudy V, Perlmutter RM, Kaushansky K, Roberts JM (1996) A syndrome of multiorgan hyperplasia with features of gigantism, tumorigenesis, and female sterility in p27(Kip1)-deficient mice. Cell 85:733-744

34. Kiyokawa H, Kineman RD, Manova-Todorova KO, Soares VC, Hoffman ES, Ono M, Khanam D, Hayday AC, Frohman LA, Koff A (1996) Enhanced growth of mice lacking the cyclin-dependent kinase inhibitor function of p27(Kip1). Cell 85:721-732

35. Nakayama K, Ishida N, Shirane M, Inomata A, Inoue T, Shishido N, Horii I, Loh DY, Nakayama K (1996) Mice lacking p27(Kip1) display increased body size, multiple organ hyperplasia, retinal dysplasia, and pituitary tumors. Cell 85:707-720

36. Lenardo M, Chan KM, Hornung F, McFarland H, Siegel R, Wang J, Zheng L (1999) Mature T lymphocyte apoptosis-immune regulation in a dynamic and unpredictable antigenic environment. Annu Rev Immunol 17:221-253

37. Mittrucker HW, Kaufmann SH (2000) Immune response to infection with Salmonella typhimurium in mice. J Leukoc Biol $67: 457-463$ 